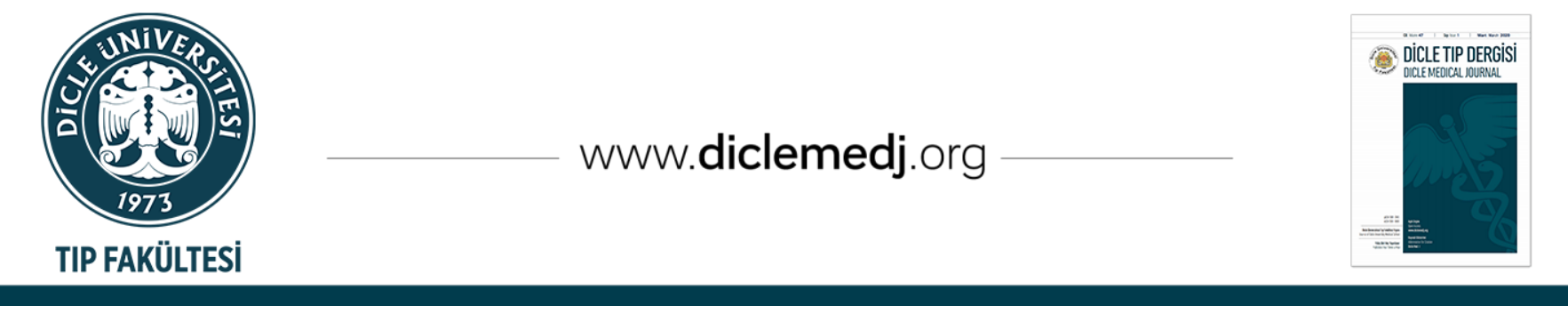

Özgün Araștırma / Original Article

\title{
Tıp Fakültesi Öğrencilerinin Sağlıklı Yaşam Biçimi Davranışları ve İlişkili Faktörler
}

\author{
Mehtap Gömleksiz ${ }^{\text {iD }}{ }^{1}$, Burkay Yakar ${ }^{\text {iD }}{ }^{1}$, Edibe Pirinçci ${ }^{(D 2}$ \\ 1 Fırat Üniversitesi, Tıp Fakültesi, Aile Hekimliği Anabilim Dalı, Elazı̆̆, Türkiye \\ 2 Fırat Üniversitesi, Tıp Fakültesi, Halk Sağlı̆̆ı Anabilim Dalı, Elazı̆̆, Türkiye
}

Geliş: 25.02.2020; Revizyon: 25.03.2020; Kabul Tarihi: 08.04.2020

Öz

Amaç: Araştırmamızda Tıp Fakültesi öğrencilerinin sağlıklı yaşam davranış düzeylerini ve sağlıklı yaşam davranışlarına etki eden faktörlerin araştırılması amaçlanmıştır.

Yöntemler: Kesitsel ve tanımlayıcı tipte tasarlanan çalışmanın evrenini bir tıp fakültesinde 2017-2018 eğitim yılında öğrenim gören tüm öğrenciler ( $\mathrm{n}=989$ kişi) oluşturmuştur. Çalışmada öğrencilerin 711'ine (katılım oranı \%71.9) ulaşılmıştır. Çalışma verileri sosyodemografik anket formu ve Sağlıklı Yaşam Biçimi Davranışları Ölçeği II (SYBD) kullanılarak elde edilmiştir. Verilerin analizi SPSS 22.0 paket programı ile t testi ve varyans analizi kullanılarak değerlendirilmiştir ve $\mathrm{p}<0.05$ değeri anlamlı kabul edilmiştir.

Bulgular: Öğrencilerin SYBD ölçeği genel ortalaması 124.79£17.94 puandı. Sosyoekonomik düzey, yaş, düzenli egzersiz ve hobi, SYBD ölçek puanına etki eden faktörlerdi $(\mathrm{p}<0.05)$. Erkek öğrencilerin fiziksel aktivite alt ölçeğinden kadın öğrencilere göre daha yüksek puan aldıkları saptanmıştır ( $<<0.05)$. Kadın öğrencilerin kişilerarası ilişki alt ölçeğinden erkek öğrencilere göre daha yüksek puan aldıkları saptanmıștır ( $\mathrm{p}<0.05)$.

Sonuç: Tıp Fakültesi Öğrencilerinin sağlıklı yaşam biçimi davranışları orta düzeyde bulunmuştur. Geleceğin sağlık çalışanları adayları ve toplumun rol-modelleri olan tıp öğrencileri, sağlıklı yaşam biçimi davranışlarının önemini kavramaları ve bu davranışları günlük hayata geçirmeleri bakımından desteklenmelidir.

Anahtar kelimeler: Sağlık davranışı; sağlıklı yaşam tarzı; tıp fakültesi öğrencileri

DOI: 10.5798/dicletip.755736

Correspondence / Yazışma Adresi: Burkay Yakar, Fırat Üniversitesi Tıp Fakültesi Aile Hekimliği AD, Elazığ, Türkiye e-mail: byakar@firat.edu.tr 


\title{
Healthy Life Style Behaviours of Medical Faculty Students and Related Factors
}

\begin{abstract}
Objective: The aim of this study was to investigate the healthy life behavior levels of the students of the Faculty of Medicine and the factors affecting the healthy life behaviors

Methods: The universe of this descriptive study consisted of all students ( $n=989)$ studying at Firat University, Faculty of Medicine in 2017-2018 academic year. 711 of the students included in the research were reached and the participation rate was 71.9\%. The study data were obtained by using sociodemographic questionnaire form and Healthy Lifestyle Behavior Scale II (HLBS-II). Data were analyzed using SPSS 22.0 package program with t test and variance analysis, and $\mathrm{p}<0.05$ was considered significant.

Results: The mean score of the students was calculated to be $124.79 \pm 17.94$ points. Those who perceived their health status as moderate and good, who perceived their socioeconomic status as medium and high, those who were 21 years or younger, and those who stated that they had a hobby had higher mean scores in HLSB scale $(\mathrm{p}<0.05)$. Male students got higher scores on physical activity subscale than female students did $(\mathrm{p}<0.05)$. Female students got higher scores on interpersonal relationship subscale than male students did $(\mathrm{p}<0.05)$.

Conclusions: The healthy lifestyle behaviors of the students of the Faculty of Medicine were found to be moderate level. The medical students who are future health care workers and role-models of society should be supported in order to make them understand the importance of healthy lifestyle behaviors and to implement these behaviors in daily life.
\end{abstract}

Keywords: Health behavior; healthy lifestyle; medicalstudents

\section{GİRiş}

Bireylerin sağlığı üzerinde etki eden davranış ve aktiviteleri kendi sağllk durumlarına uygun ve olumlu davranışlar olarak uygulayabilmesi sağlıklı yaşam biçimi olarak tanımlanmaktadır ${ }^{1}$.Yirminci yüzyılın ortalarına kadar insanlarda toplu ölümlere yol açan tifo, kolera gibi salgın hastalıkların yerini, günümüzde hipertansiyon, obezite, diyabet, kalp hastalıkları ve Kazanılmış Bağışıklık Yetersizliği Sendromu (AcquiredImmuneDeficiencySyndrome= AIDS) gibi hastalıkların aldığı görülmektedir. $\mathrm{Bu}$ hastalıklardan korunmak için topluma sağlıklı yaşam biçimi davranışlarının öğretilmesi ve geliştirilmesi gerekmektedir².

Sağlı̆̆ı geliştiren yaşam tarzı davranışı, beslenme değerlerine, kendini sosyal ortamlarda ifade etme becerisine, kişinin kendi sağlığının sorumluluğunu üstlenme, egzersiz yapma, bireyler arasinda destek ve stres yönetimi üzerine kuruludur ${ }^{3}$. Sağlığı geliştirme, bireylerin eğitim, ekonomik, kuruluş ve çevresel desteklerden faydalanarak sağlıklarını denetleme ve geliştirmelerini içeren bir süreçtir ${ }^{4}$. Risklerin azaltılması ve sağlığın geliştirilmesi, yalnızca ölümlerin ve sakatlıkların önlenmesini sağlamayacak, aynı zamanda hükümetlerin ve toplumun katılımının sağlandığı bir ortam yaratarak sosyal değerlerinin güçlenmesini de sağlayacaktır ${ }^{5}$.

Üniversite yaşamı, bireylerin kişiliğinde, mesleki eğitim, gelişim ve yaşamında, sağlık davranışları geliştirmesinde önemli değişikliklerin yaşandığı bir dönemdir6. Yaşam stilindeki değişiklikler ve alışılmadık yaşam koşulları birçok öğrenci için yetersiz beslenme, yeterli olmayan egzersiz gibi sağlıksız davranışlara neden olmaktadır'́r. Toplumdaki her bireyin sağlık kavramını iyileștirmek için sorumluluk alması ve sağlıklı yaşam modelini günlük rutininin bir parçası haline getirmesi önemlidir ancak sağlık çalışanlarının bu konudaki sorumluluğu daha fazladır. Sağlık hizmet sunucularının yaşam biçimleri, sağlık eğitimi hizmeti sundukları toplum tarafından rol model olarak örnek alınabilir ${ }^{7}$. Bu sebepten tıp fakültesi öğrencilerinin sağlıklı yaşam davranışı sergilemeleri ve olumsuz davranışa sebep olan etmenlerin saptanması elzemdir. Konu ile ilgili birçok çalışma, demografik değișkenler ile sağlığı geliştirici davranışlar 
arasındaki ilişkileri bildirmiștir. Yaș, cinsiyet, beden kitle indeksi (BKI), ekonomik durum, beslenme ve düzenli fiziksel aktivite ile sağllğ geliştirici davranışlar arasında önemli ilişki olduğu gösterilmiştir8-16.

Literatür verileri ışığında özellikle topluma rol model olan sağlık çalışanlarının sağlıklı yaşam biçimi davranışları sergilemelerinin önemli olduğu düşünülmüştür. Bu bağlamda ileride topluma rol model olacak tıp fakültesi öğrencilerin sağlıklı yaşam biçimi davranışları ve etkileyen faktörlerin araştırılmasının toplum sağlı̆̆ını korumaya katkı sağlayabileceği düşünülmüştür. Bu çalışma, Fırat Üniversitesi Tıp Fakültesindeki öğrencilerin sağlıklı yaşam biçimi davranışlarını ve olumsuz davranışlara sebep olan etmenleri incelemeyi amaçlamıştır.

\section{YÖNTEMLER}

\section{Çalışma dizaynı ve popülasyon}

Tanımlayıcı tipte tasarlanan araştırmamızın evrenini, bir üniversitenin tıp fakültesine 20172018 eğitim öğretim döneminde kayıtlı tüm öğrenciler $\quad(n=989) \quad$ oluşturmuştur. Araştırmanın evrenini oluşturan 989 öğrencinin 711'ine ulaşılmıştır ve katılım oranı \%71,9'dur. Araştırmanın saha çalışması, MartAğustos 2018 tarihlerinde yapılmıştır. Araștırma için, Fırat Üniversitesi Girişimsel Olmayan Araştırmalar Etik Kurulu'nun 22.03.2018 tarih ve 06 sayılı yazısı ile etik onay alınmıştır.

\section{Anket formları}

Çalışmamızın bağımlı değişkeni, sağlıklı yaşam biçimi davranışlarıdır. Bağımsız değişkenleri sorgulamak için, literatür verileri değerlendirilerek hazırlanan sorulardan oluşan sosyodemografik anket formu ve Sağlıklı Yaşam Biçimi Davranışları Ölçeği'ni (SYBD) etkilediği düşünülen sorulara yer verilmiştir. Sağlıklı Yaşam Biçimi Davranışları Ölçeğinin 48 madde ve 6 faktörden oluşan ilk versiyonu Pender'in sağlı̆̆ geliştirme modeli temelinde, Walker tarafından 1987 yılında geliştirilmiştir. Ölçek daha sonra, 1996 yllında Walker ve ark. ${ }^{17}$ tarafindan 4 madde daha ilave edilerek 52 maddeden oluşan SYBD II oluşturulmuştur. Ölçeğin Türkçe versiyonu ve geçerlik-güvenirlik çalışması 2008 yılında Bahar ve ark.18 tarafından yapılmıştır. Bahar ve ark. ${ }^{18}$ ölçeğin Alpha güvenirlik katsayısını 0.92ölçeğin alt boyutlarının güvenirlik katsayılarını ise sırasıyla; sağlık sorumluluğu 0.77 , fiziksel aktivite ve egzersiz 0.79 , beslenme 0.68 , manevi gelişim 0.79, kişilerarası destek 0.80 , stres yönetimi 0.64 olarak bildirmişlerdir. Ölçeğin Türkçe versiyonu, dörtlü Likert'e göre [1 (hiçbir zaman), 2 (bazen), 3 (sık sık) ve 4 (düzenli olarak)] tümü olumlu 52 madde içermektedir. Katılımcılar ölçekten alacakları puan 52-208 arasında değişmektedir. Ölçek; manevi gelişim (tinsellik), sağlık sorumluluğu, fiziksel aktivite, beslenme, kişilerarası ilişki ve stres yönetimi olmak üzere 6 alt birim içermektedir.

\section{Veri toplama}

Araștırma verileri, ilgili anket formları ile katılımcıların öğrenim gördükleri dersliklere gidilerek uygulanmıştır. Katılımcılara gerekli bilgilendirmeler yapıldıktan sonra, anket formları dağıtılmış ve katılımcılardan doldurmaları istenmiştir. Katılımcıların sorularını yanıtlamak için, bir araştırmacı veri toplama süreci boyunca hazırda beklemiştir. Araştırmamızın 989 kişiden oluşan evreninde çalışmaya katılmaya gönüllü olan 800 katılımcıya, anket formları dağıtılmıștır. Dağıtılan 800 anket formunun yapılan incelemesi sonucunda 89 tanesinin hatalı ve eksik doldurulduğu tespit edildiğinden çalışmadan çıkarılmıştır. Sonuç olarak araştırmamız 711 katılımcının verileri ile yürütülmüştür.

\section{İstatistiksel analiz}

Araştırma verileri, Statistical Package for the Social Sciences (SPSS) versiyon 22.0 istatistik paket programına kaydedilmiștir. Verilerin hata kontrolleri, analizleri ve tabloları aynı 
programda yapılmıştır. İstatistiksel değerlendirmelerde $t$ testi ve varyans analizleri (ANOVA ve Kruskal Wallis testleri) kullanılmış, gruplar arasında $\mathrm{ki}$ istatistiksel farklılığın tespitinde çoklu karşılaştırma testlerinden Tukey HSD testi uygulanmıştır. Ortalamalar standart sapma ile birlikte verilmiştir (OrtıSS) ve $p<0.05$ istatistiksel anlamlılık olarak değerlendirilmiştir.

\section{BULGULAR}

Araştırma kapsamına alınan öğrencilerin $\% 50,6$ 's (n=360) kadın, \%49,4'ü (n=351) erkek öğrencidir. Tıp fakültesi öğrencilerinin yaş ortalaması 21,74 $\pm 2,34$ (min:18, maks:40)'dür. Araştırmaya katılan öğrencilerin ortalama boy uzunluğu 170,94 $\pm 8,68 \mathrm{~cm}$ (min:153 cm, maks: $200 \mathrm{~cm}$ ), ortalama kiloları 67,11 $\pm 13,04 \mathrm{~kg}$ (min:43 kg, maks:111 kg), Beden Kitle İndeksi (BKİ) ortalamaları ise $22,81 \pm 3,12 \mathrm{~kg} / \mathrm{m}^{2}$ (min:16,56, maks:34,95) olarak saptanmıştır. Araştırma kapsamına alınan öğrencilerin sosyodemografik özellikleri Tablo 1'de verilmiştir. (Tablo I).

Tablo I: Öğrencilerin sosyodemografik özelliklerine göre dağılımı

\begin{tabular}{|c|c|c|c|c|c|}
\hline Özellik & $\begin{array}{l}\text { Sayı } \\
\text { (n) }\end{array}$ & $\begin{array}{l}\text { Yüzde } \\
(\%)\end{array}$ & Özellik & $\begin{array}{r}\text { Sayl } \\
\text { (n) }\end{array}$ & $\begin{array}{l}\text { Yüzd } \\
\text { e (\%) }\end{array}$ \\
\hline Cinsiyet & & & Baba eğitim düzeyi & & \\
\hline Kadın & 360 & 50,6 & Okuryazar değil & 14 & 2,0 \\
\hline Erkek & 351 & 49,4 & İlkokul mezunu ve altı & 140 & 19,7 \\
\hline Yaş grupları & & & Ortaokul & 72 & 10,1 \\
\hline 21 yaş ve altı & 339 & 47,7 & Lise & 161 & 22,6 \\
\hline $\begin{array}{l}22 \text { yaş ve } \\
\text { üzeri }\end{array}$ & 372 & 52,3 & Üniversite & 324 & 45,6 \\
\hline Sinıf & & & Sağlık durumu algısı & & \\
\hline 1.Sinıf & 141 & 19,8 & İyi & 461 & 64,8 \\
\hline 2.sinif & 121 & 17,0 & Orta & 237 & 33,3 \\
\hline 3.sinıf & 116 & 16,3 & Kötü & 13 & 1,8 \\
\hline 4. $\sin ı f$ & 115 & 16,2 & $\begin{array}{r}\text { Sigara kullanma } \\
\text { durumu }\end{array}$ & & \\
\hline
\end{tabular}

\begin{tabular}{|c|c|c|c|c|c|}
\hline 5. sinif & 100 & 14,1 & Kullaniyor & 205 & 28,8 \\
\hline 6.sinif & 118 & 16,6 & Kullanmıyor & 506 & 71,2 \\
\hline Aile tipi & & & $\begin{array}{r}\text { Alkol kullanma } \\
\text { durumu }\end{array}$ & & \\
\hline $\begin{array}{l}\text { Çekirdek } \\
\text { aile }\end{array}$ & 624 & 87,7 & Kullaniyor & 88 & 12,4 \\
\hline Geniş aile & 80 & 11,3 & Kullanmiyor & 623 & 87,6 \\
\hline $\begin{array}{l}\text { Parçalanmış } \\
\text { aile }\end{array}$ & 7 & 1,0 & $\begin{array}{r}\text { Kronik hastalığ } \\
\text { olma durumu }\end{array}$ & & \\
\hline \multicolumn{2}{|c|}{ Mezun oldukları lise } & & Var & 86 & 10,4 \\
\hline Devlet okulu & 611 & 85,9 & Yok & 625 & 89,6 \\
\hline Özel okul & 66 & 9,3 & $\begin{array}{r}\text { BMI(ağırlık } \\
\left.(\mathrm{kg}) / \text { boy }^{2}\left(\mathrm{~m}^{2}\right)\right)\end{array}$ & & \\
\hline Yatılı okul & 34 & 4,8 & Zayif & 48 & 6,8 \\
\hline \multicolumn{2}{|c|}{$\begin{array}{l}\text { Sosyoekonomik } \\
\text { düzey algısı }\end{array}$} & & Normal & 512 & 72,0 \\
\hline Alt (düşük) & 74 & 10,4 & Fazla kilolu & 133 & 18,7 \\
\hline Orta & 591 & 83,1 & Obez & 18 & 2,5 \\
\hline Üst (yüksek) & 46 & 6,5 & $\begin{array}{r}\text { Düzenli egzersiz } \\
\text { yapma }\end{array}$ & & \\
\hline \multicolumn{2}{|c|}{ Anne eğitim düzeyi } & & Yapıyor & 231 & 32,5 \\
\hline $\begin{array}{l}\text { Okuryazar } \\
\text { değil }\end{array}$ & 78 & 11,0 & Yapmiyor & 480 & 67,5 \\
\hline $\begin{array}{l}\text { İlkokul ve } \\
\text { altı }\end{array}$ & 251 & 35,3 & Hobisi olma durumu & & \\
\hline Ortaokul & 84 & 11,8 & Var & 429 & 60,3 \\
\hline Lise & 145 & 20,4 & Yok & 282 & 39,7 \\
\hline Üniversite & 153 & 21,5 & & & \\
\hline Toplam & 711 & 100.0 & & 711 & $\begin{array}{c}100 \\
0\end{array}$ \\
\hline
\end{tabular}

Araştırmaya katılan öğrencilerin SYBD ölçeği puan ortalaması 124,79 $\pm 17,94$, alınan en düşük puan 66 en yüksek puan 188'di. SYBD ölçeği puan ortalaması ve alt ölçeklerden alınan puanlar Tablo 2'de sunulmuştur. (Tablo II). 
Tablo II: Öğrencilerin Sağlıklı Yaşam Biçimi Davranışları Ölçeği alt bileșenlerine ait puan ortalamalarının dağılımı

\begin{tabular}{|c|c|c|}
\hline $\begin{array}{l}\text { SYBDÖ ve Alt } \\
\text { Bileşenleri }(n=711)\end{array}$ & Puan ortalaması $\pm S S$ & $\begin{array}{l}\text { Min- } \\
\text { maks }\end{array}$ \\
\hline Sağlık Sorumluluğu & $19.86 \pm 4.10$ & $9-34$ \\
\hline Fiziksel Aktivite & $16.96 \pm 4.39$ & $8-32$ \\
\hline Beslenme & $19.74 \pm 3.69$ & $9-32$ \\
\hline Manevi Gelişim & $24.06 \pm 4.50$ & $9-36$ \\
\hline Kişilerarası İlişki & $25.01 \pm 4.28$ & $12-36$ \\
\hline Stres Yönetimi & $19.14 \pm 3.67$ & $9-32$ \\
\hline Toplam puan & $124.79 \pm 17.94$ & $66-188$ \\
\hline
\end{tabular}

Katılımcıların SYBD ölçeğinden aldıkları puana etki eden faktörleri incelediğimizde 21 yaş altında olan $(p=0,026)$, sosyoekonomik düzeyini yüksek bildiren $(p=0,002)$, sağlık durumlarını iyi algılayan $(\mathrm{p}=0,001)$, egzersiz yaptığını beyan eden $(\mathrm{p}=0,001)$ ve hobisi olan $(p=0,001)$ katılımcıların SYBD ölçeği toplam puanlarının anlamlı düzeyde yüksek olduğu saptanmıştır. SYBD ölçeğinin toplam ve alt boyutlarından alınan puana etki eden faktörler Tablo 3'de sunulmuştur. (Tablo III).

Tablo III: Öğrencilerin bazı değişkenlere göre Sağlıklı Yaşam Biçimi Davranışları Ölçeği toplam puanı ile alt bileșenlerin puan ortalamalarının dağılımı

\begin{tabular}{|c|c|c|c|c|c|c|c|}
\hline Özellikler & 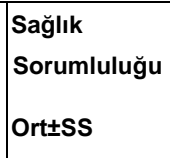 & $\begin{array}{l}\text { Fiziksel Aktivite } \\
\text { Ort } \pm \text { SS }\end{array}$ & $\begin{array}{l}\text { Beslenme } \\
\text { Ort } \pm \text { Ss }\end{array}$ & $\begin{array}{l}\text { Manevi } \\
\text { Gelişim OrtıSS }\end{array}$ & $\begin{array}{l}\text { Kişilerarası Ilişki } \\
\text { OrttSS }\end{array}$ & $\begin{array}{l}\text { Stres Yönetimi } \\
\text { OrtıSS }\end{array}$ & 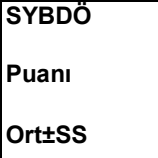 \\
\hline \multicolumn{8}{|l|}{ Cinsiyet } \\
\hline Kadın & $19.88 \pm 3.93$ & $16.16 \pm 3.90$ & $19.62 \pm 3.68$ & $23.83 \pm 4.26$ & $25.45 \pm 4.13$ & $18.92 \pm 3.49$ & $123.89 \pm 16.90$ \\
\hline Erkek & $19.84 \pm 4.27$ & $17.77 \pm 4.71$ & $19.86 \pm 3.71$ & $24.29 \pm 4.73$ & $24.57 \pm 4.39$ & $19.37 \pm 3.84$ & $125.72 \pm 18.94$ \\
\hline p değeri & $\mathrm{P}=0.882$ & $P=0.001$ & $P=0.397$ & $P=0.179$ & $P=0.006$ & $P=0.100$ & $P=0.174$ \\
\hline \multicolumn{8}{|l|}{ Yaş grupları } \\
\hline 21 yaş ve altı & $20.20 \pm 4.13$ & $17.21 \pm 4.34$ & $19.72 \pm 3.84$ & $24.23 \pm 4.49$ & $25.35 \pm 4.22$ & $19.61 \pm 3.87$ & $126.36 \pm 18.40$ \\
\hline 21 yaş üzeri & $19.55 \pm 4.05$ & $16.72 \pm 4.43$ & $19.75 \pm 3.56$ & $23.89 \pm 4.51$ & $24.71 \pm 4.31$ & $18.7 \pm 3.43$ & $123.37 \pm 17.42$ \\
\hline p değeri & $P=0.035$ & $P=0.140$ & $P=0.931$ & $P=0.313$ & $P=0.047$ & $P=0.001$ & $P=0.026$ \\
\hline \multicolumn{8}{|c|}{ Sosyoekonomik düzey algısı } \\
\hline Alt (düşük) & $19.24 \pm 4.43^{*}$ & $16.17 \pm 4.32^{*}$ & $19.02 \pm 3.45^{*}$ & $22.72 \pm 4.83^{*}$ & $24.21 \pm 4.85$ & $18.77 \pm 3.92$ & $120.16 \pm 18.04$ \\
\hline Orta & $19.80 \pm 3.98^{*}$ & $16.89 \pm 4.31^{*}$ & $19.72 \pm 3.66$ & $24.18 \pm 4.35^{*}$ & $25.05 \pm 4.14$ & $19.13 \pm 3.60$ & $124.80 \pm 17.51$ \\
\hline Üst (yüksek) & $21.67 \pm 4.58^{*}$ & $19.08 \pm 4.96^{*}$ & $21.04 \pm 4.18^{*}$ & $24.63 \pm 5.45$ & $25.80 \pm 4.90$ & $19.95 \pm 4.13$ & $132.19 \pm 21.04$ \\
\hline p değeri & $P=0.004$ & $P=0.001$ & $P=0.014$ & $\mathrm{P}=0.022$ & $P=0.123$ & $P=0.221$ & $P=0.002$ \\
\hline \multicolumn{8}{|c|}{ Anne eğitim düzeyi } \\
\hline Ortaokul altı & $19.60 \pm 3.92$ & $16.55 \pm 4.29^{*}$ & $19.63 \pm 3.48$ & $24.52 \pm 4.11^{*}$ & $25.15 \pm 4.06$ & $19.22 \pm 3.54$ & $124.70 \pm 16.79$ \\
\hline Lise & $20.24 \pm 3.79$ & $17.22 \pm 4.15$ & $20.02 \pm 3.82$ & $23.62 \pm 5.09$ & $24.48 \pm 4.73$ & $19.03 \pm 3.93$ & $124.62 \pm 19.30$ \\
\hline Üniversite & $20.22 \pm 4.76$ & $17.79 \pm 4.75^{*}$ & $19.76 \pm 4.11$ & $23.21 \pm 4.76^{*}$ & $25.15 \pm 4.40$ & $19.05 \pm 3.79$ & $125.22 \pm 19.66$ \\
\hline p değeri & $P=0.126$ & $P=0.008$ & $P=0.555$ & $P=0.004$ & $P=0.239$ & $P=0.819$ & $P=0.946$ \\
\hline \multicolumn{8}{|c|}{ Baba eğitim düzeyi } \\
\hline Ortaokul altı & $19.47 \pm 3.64$ & $16.56 \pm 4.04$ & $19.70 \pm 3.39$ & $24.24 \pm 4.40$ & $24.96 \pm 4.19$ & $19.07 \pm 3.26$ & $124.03 \pm 15.94$ \\
\hline Lise & $19.98 \pm 4.17$ & $16.73 \pm 4.07$ & $19.47 \pm 3.61$ & $23.81 \pm 4.74$ & $24.99 \pm 4.58$ & $19.13 \pm 3.97$ & $124.15 \pm 18.25$ \\
\hline Üniversite & $20.07 \pm 4.35$ & $17.34 \pm 4.75$ & $19.89 \pm 3.93$ & $24.05 \pm 4.45$ & $25.06 \pm 4.20$ & $19.20 \pm 3.79$ & $125.64 \pm 19.09$ \\
\hline
\end{tabular}


Gomleksiz M., Yakar B., Pirincci E.

\begin{tabular}{|c|c|c|c|c|c|c|c|}
\hline p değeri & $P=0.221$ & $P=2.408$ & $P=0.499$ & $P=0.660$ & $P=0.962$ & $P=0.917$ & $P=0.512$ \\
\hline \multicolumn{8}{|l|}{ Sağlık durum algısı } \\
\hline Iyi & $20.28 \pm 4.10^{*}$ & $17.35 \pm 4.45^{*}$ & $20.05 \pm 3.45^{*}$ & $24.57 \pm 4.38^{*}$ & $25.29 \pm 4.21^{*}$ & $19.43 \pm 3.58^{*}$ & $126.99 \pm 17.69$ \\
\hline Orta & $19.23 \pm 3.86^{*}$ & $16.25 \pm 4.07^{*}$ & $19.19 \pm 4.06^{*}$ & $23.17 \pm 4.45^{*}$ & $24.59 \pm 4.21$ & $18.64 \pm 3.68^{*}$ & $121.10 \pm 17.22$ \\
\hline Kötü & $16.61 \pm 5.34^{*}$ & $15.84 \pm 6.18$ & $18.53 \pm 3.88$ & $21.76 \pm 6.44$ & $23.23 \pm 6.77^{*}$ & $18.15 \pm 5.41$ & $114.15 \pm 25.29$ \\
\hline p değeri & $P=0.002$ & $P=0.005$ & $P=0.007$ & $P=0.001$ & $P=0.048$ & $P=0.016$ & $P=0.001$ \\
\hline \multicolumn{8}{|l|}{ BKI } \\
\hline Zayıf & $20.08 \pm 4.02$ & $15.04 \pm 4.17^{*}$ & $19.45 \pm 4.05$ & $23.60 \pm 3.91$ & $25.62 \pm 4.02$ & $19.16 \pm 3.66$ & $122.97 \pm 15.03$ \\
\hline Normal & $19.82 \pm 4.11$ & $16.98 \pm 4.37^{*}$ & $19.60 \pm 3.70$ & $24.03 \pm 4.48$ & $24.86 \pm 4.25$ & $19.16 \pm 3.70$ & $124.49 \pm 18.20$ \\
\hline Fazla Kilolu & $20.02 \pm 4.06$ & $17.57 \pm 4.42^{*}$ & $20.29 \pm 3.53$ & $24.34 \pm 4.70$ & $25.31 \pm 4.40$ & $19.06 \pm 3.63$ & $126.61 \pm 18.24$ \\
\hline Obez & $19.33 \pm 4.57$ & $16.77 \pm 4.23$ & $20.27 \pm 3.52$ & $23.77 \pm 5.09$ & $25.50 \pm 4.80$ & $19.27 \pm 3.28$ & $124.94 \pm 15.74$ \\
\hline p değeri & $P=0.877$ & $P=0.008$ & $P=0.230$ & $P=0.775$ & $P=0.485$ & $P=0.990$ & $P=0.571$ \\
\hline \multicolumn{8}{|c|}{ Sigara kullanma durumu } \\
\hline Kullanıyor & $19.43 \pm 4.45$ & $17.28 \pm 4.74$ & $19.18 \pm 4.02$ & $23.57 \pm 4.42$ & $25.23 \pm 4.51$ & $18.84 \pm 3.75$ & $123.56 \pm 19.45$ \\
\hline Kullanmıyor & $20.03 \pm 3.94$ & $16.83 \pm 4.24$ & $19.96 \pm 3.53$ & $24.25 \pm 4.52$ & $24.93 \pm 4.18$ & $19.27 \pm 3.63$ & $125.29 \pm 17.29$ \\
\hline p değeri & $P=0.077$ & $P=0.213$ & $P=0.01$ & $P=0.065$ & $P=0.385$ & $P=0.166$ & $P=0.243$ \\
\hline \multicolumn{8}{|c|}{ Egzersiz yapma durumu } \\
\hline Yapıyor & $20.37 \pm 4.57$ & $20.14 \pm 4.38$ & $20.61 \pm 3.76$ & $24.84 \pm 4.58$ & $25.78 \pm 4.41$ & $20.45 \pm 3.61$ & $132.21 \pm 18.54$ \\
\hline Yapmıyor & $19.62 \pm 3.83$ & $15.42 \pm 3.48$ & $19.31 \pm 3.59$ & $23.68 \pm 4.42$ & $24.65 \pm 4.17$ & $18.52 \pm 3.53$ & $121.22 \pm 16.52$ \\
\hline p değeri & $P=0.021$ & $P=0.001$ & $P=0.001$ & $P=0.001$ & $P=0.001$ & $P=0.001$ & $P=0.001$ \\
\hline \multicolumn{8}{|c|}{ Kronik hastalık durumu } \\
\hline Var & $20.33 \pm 3.99$ & $16.82 \pm 4.37$ & $20.17 \pm 4.08$ & $23.67 \pm 4.63$ & $24.97 \pm 4.28$ & $19.18 \pm 3.83$ & $125.17 \pm 17.79$ \\
\hline Yok & $19.80 \pm 4.11$ & $16.97 \pm 4.39$ & $19.68 \pm 3.64$ & $24.11 \pm 4.48$ & $25.02 \pm 4.28$ & $19.14 \pm 3.65$ & $124.74 \pm 17.93$ \\
\hline p değeri & $P=0.256$ & $P=0.761$ & $P=0.247$ & $P=0.397$ & $\mathrm{P}=0.921$ & $P=0.921$ & $P=0.836$ \\
\hline \multicolumn{8}{|c|}{ Hobisi olma durumu } \\
\hline Var & $20.06 \pm 4.02$ & $17.49 \pm 4.50$ & $20.13 \pm 3.80$ & $24.89 \pm 4.38$ & $25.57 \pm 4.23$ & $19.52 \pm 3.64$ & $127.68 \pm 17.72$ \\
\hline Yok & $18.57 \pm 3.65$ & $16.15 \pm 4.09$ & $19.14 \pm 3.45$ & $22.78 \pm 4.38$ & $24.17 \pm 4.23$ & $18.57 \pm 3.65$ & $120.40 \pm 17.42$ \\
\hline p değeri & $P=0.119$ & $P=0.001$ & $P=0.001$ & $P=0.001$ & $P=0.001$ & $P=0.001$ & $P=0.001$ \\
\hline \multicolumn{8}{|l|}{ Aile tipi } \\
\hline Çekirdek aile & $20.00 \pm 4.04^{*}$ & $17.00 \pm 4.43$ & $19.81 \pm 3.69$ & $24.00 \pm 4.53$ & $25.06 \pm 4.26$ & $19.12 \pm 3.68$ & $125.02 \pm 17.99$ \\
\hline Geniş aile & $19.08 \pm 4.23$ & $16.60 \pm 4.13$ & $19.41 \pm 3.59$ & $24.65 \pm 4.07$ & $24.58 \pm 4.16$ & $19.40 \pm 3.42$ & $123.73 \pm 16.93$ \\
\hline Parçalanmış aile & $16.28 \pm 5.40^{*}$ & $17.28 \pm 4.07$ & $16.71 \pm 4.60$ & $22.57 \pm 5.94$ & $\mid 25.57 \pm 7.29$ & $18.14 \pm 5.63$ & $116.57 \pm 25.13$ \\
\hline p değeri & $P=0.011$ & $P=0.728$ & $P=0.061$ & $P=0.326$ & $P=0.603$ & $P=0.633$ & $P=0.397$ \\
\hline
\end{tabular}

*Tukey HSD testi ile farklılı̆̆ın kaynaklandı̆̆ı gruplar. 


\section{TARTIŞMA}

Araştırmamızda, tıp fakültesi öğrencilerinin Sağlıklı Yaşam Biçimi Davranışları Ölçeği (SYBD) ölçeği genel puan ortalaması $124,79 \pm 17,94$ olarak bulunmuştur. Literatürde yapılan araştırmalarda ülkemizde tıp fakültesi öğrencileri ve sağlık bilimleri öğrencileri arasında yapılan benzer araştırmalarda SYBD

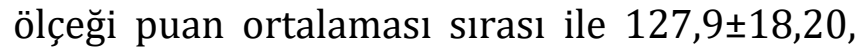
$127,5 \pm 17,45,130,69 \pm 19,22,124,30 \pm 17,92$ ve $125,62 \pm 19,40$ olarak yurt dişında yapılan benzer çalışmalarda ise SYBD ölçeği puan ortalaması orta düzey olarak bildirilmiştir ${ }^{14-}$ 16,22. Elde ettiğimiz verilerin genel literatür verileri ile benzerlik gösterdiği saptanmıştır. Araştırmamızda SYBD ölçeğinin alt kırımlarından alınan puanlar yüksekten düşüğe doğrusırasıyla; kişilerarası ilişki, manevi gelişim, sağlık sorumluluğu, beslenme alışkanlığı, stres yönetimi ve fiziksel aktivite boyutlarına ait olduğu saptanmıştır. Elde ettiğimiz bulgular, literatür verileri ile kıyaslandığında alt grup puanlardan alınan puan sıralamasının benzer olduğu saptanmıştır. Literatür ile uyumlu olarak alt fiziksel aktivite puanı alt grup puanlar içerisinde en düşük ortalamaya sahip gruptur8,9,12,13,23,24. İran'da yapılan benzer çalışmada fiziksel aktivite en düşük ortalamaya sahiptir25. Amerika'da bir grup öğrenci arasında yapılan çalışmada, en düşük puan ortalamaları sırasıyla; fiziksel aktivite, beslenme, sağlık sorumluluğu şeklinde belirtilmiştir ${ }^{26}$. Öğrenciler arasında yapılan çalışmalarda genel olarak fiziksel aktivite alt boyutundan alınan puan, çalışmamızla benzer şekilde düşük bulunmuştur. Literatür verileri ve elde ettiğimiz bulgular ıșığında, öğrencilerin fiziksel aktivite yapmamalarının önünde ki engellerin tespit edilerek kaldırılması ve fiziksel aktiviteye teşvik edici, fiziksel aktivite alışkanlığı kazandırıcı faaliyetlerin hayata geçirilmesiyle, öğrencilerin sağlıklı yaşam davranışı geliştirmelerine katkı sağlanabileceği düşünülmüştür.
Araștırmamızda, cinsiyet ile SYBD ölçek puanı arasında anlamlı ilişki saptanmamıştır. Ölçeğin alt gruplarının puan ortalaması değerlendirmesinde, erkeklerde fiziksel aktivite puanı, kadın öğrencilerin ise kişiler arası ilişki alt grup puanları daha yüksek saptanmıștır $(p<0.05)$. Yurt içi ve yurt dişı çalışmalar incelendiğinde, bir kısmında çalışmamızla uyumlu olarak, erkek öğrencilerin fiziksel aktivite düzeyleri, kız öğrencilerden daha yüksek bulunmuştur9,10,15. Üniversite öğrencileri arasında yapılan benzer çalıșmada, kişiler arası ilişki alt ölçeğinden, kadın öğrencilerin daha yüksek puan aldıkları görülmüştür9. İleride konu ile ilgili yapılacak araștırmalarda, kız öğrencilerin fiziksel aktivite durumlarının önünde ki engellerin saptanması ve fiziksel aktivitenin arttırılmasını sağlayabilecek girişimlerin incelenmesi gerektiği düşünülmüştür.

Araştırmaya katılan öğrencilerin sınıflarına göre, SYBD ve alt boyutları incelendiğinde; SYBD puan ortalaması en yüksek ikinci sınıf öğrencilerine aittir; ancak sınıflar arası anlamlı bir fark bulunmamıştır. Alt boyut puan ortalamalarına bakıldığında $\mathrm{da}$, sınıflar arası anlamlı bir fark görülmemiștir. Japonya'da üniversite öğrencileri arasında yapılan bir çalışmada, SYBD II puanıyla sınıflar arasında negatif korelasyon olduğu görülmüştür ${ }^{14}$. Ülkemizde sağlık bilimleri öğrencileri arasında yapılan bir çalışmada, sağlık sorumluluğu alt boyutundanson sınıf öğrencilerinin, ilk yılöğrencilerine göre daha yüksek puan aldıkları görülmüştür ${ }^{9}$. $\mathrm{Bu}$ sonuçlar doğrultusunda tıp fakültesi öğrencilerinin sağlıklı yaşam davranışlarını geliştirmek için aldıkları eğitimi, davranışlara dönüştürmeleri konusunda desteklenmeleri gerektiği düşünülmüştür.

Araştırmaya katılan öğrencilerin, 21 yaş ve altı olanların SYBD ölçeği toplam puanı, sağlık sorumluluğu, kişilerarası ilişki ve stres yönetimi puan ortalamaları daha yüksek saptanmıştır 
$(\mathrm{p}<0.05)$. Nacar ve ark., verilerimizle benzer olarak düşük yaş grubunun ölçek puanlarının daha yüksek olduğunu bildirmiștir8. Bizim çalışmamızla benzer şekilde Meksika'da yapılan bir çalışmada, 25 yaş ve üzeri öğrencilerin, toplam puan, fiziksel aktivite, stres yönetimi ve kişilerarası ilişki alt grup puan ortalamalarının, 25 yaş altı öğrencilerden daha düşük olduğu bildirilmiştir ${ }^{15}$. Japonya'da üniversite öğrencilerinde yapılan bir çalışmada, birinci sınıf öğrencilerinin, üst sinıfta okuyan öğrencilere nazaran puan ortalamalarının daha yüksek olduğu bildirilmiştir ${ }^{14}$. Fakülte öğrencilerinin artan ders yükleri, mesleki beceri kazanmalarına yönelik alınan stajların yoğunluğu, gece nöbetlerinin artması stres oluşturucu olabilir.

Araştırmamızda, öğrencilerin sosyoekonomik düzeyi arttıkça, SYBD ölçeği puanı ile alt gruplarından sağlık sorumluluğu, fiziksel aktivite, beslenme alışkanlığı ve manevi gelişim puanlarının arttığı saptanmıştır ( $\mathrm{p}<0.05)$. Nacar ve ark.'nın yaptıkları çalışmada, SYBD ölçek puanı ile sosyoekonomik düzey arasında pozitif bir korelasyon olduğu bildirilmiștir ${ }^{8}$. Oral'ın çalışmasında ekonomik durumunu iyi olarak tanımlayan grupta, puan ortalamaları anlamlı oranda daha yüksek bulunmuştur ${ }^{10}$. Literatür verileri ve elde ettiğimiz bulgular yüksek sosyoekonomik seviye sahip bireylerin pozitif sağlı davranışları tutumlarının yüksek olduğunu göstermiştir.

Araştırma kapsamına anne eğitim düzeyi arttıkça fiziksel aktivite alt boyutundan alınan ortalama puanın arttığı, manevi gelişim alt boyutundan alınan ortalama puanın azaldığ görülmüştür $\quad(p<0.05)$ Oral'ın yaptığı çalışmada, annesi üniversite mezunu olanların fiziksel aktivite, sağlık sorumluluğu, kişilerarası ilişki ve toplam puanlarının daha yüksek olduğunu saptamıștır ${ }^{10}$. Yurt dışında üniversite öğrencileri arasında yapılan benzer bir çalışmada da, anne eğitim düzeyinin SYBD ve alt boyutlarını etkilemediği görülmüşsür ${ }^{27}$.
Araștırma kapsamındaki öğrencilerin baba eğitim durumunun sağlıklı yaşam biçimi davranışlarını etkilemediği görülmüştür. Tıp fakültesi öğrencileri arasında yapılan bir çalışmada, ailenin eğitim durumu arttıkça SYBD puanının da arttığı saptanmıștır ${ }^{8}$. Örnek'in üniversite öğrencileri arasında yapmış olduğu çalışmada baba eğitim düzeyinin SYBD puanını etkilemediği görülmüștür ${ }^{12}$. Aile büyüklerinin sağlık yaşam davranışları üzerinde ki etkisi yeterince aydınlatılamamıștır.

Araştırmamızda, ölçek toplam puanı ve alt grup puanlarının katılımcıların sağlık durumları üzerinde ki kendi olumlu görüşleri arttıkça pozitif olarak yükseldiği saptanmıştır. Sağlık durumunu iyi olarak görenlerde tüm puanların daha yüksek olduğu saptanmıştır $(p<0.05)$. Literatürde üniversite öğrencilerinde ve sağlıkla ilgili olan tıp fakültesi, sağllk yüksekokulu ve hemşirelik öğrencilerinde yapılan farklı çalışmalarda sağlıklarını iyi ve çok iyi olarak tanımlayanlarda, toplam ölçek puanları anlamlı olarak daha yüksek bulunmuştur ${ }^{8,11,12,28,29}$. Elde edilen veriler ışığında, bireylerin sağlıklarına verdikleri önemin, pozitif davranış, sağlıklı beslenme ve stresten korunma gibi olumlu davranışların artmasına katkı sağladığı söylenebilir.

Çalışmamızda öğrencilerin beden kitle indeksi (BKI)ve Sağlıklı Yaşam Biçimi Davranışları Ölçeği (SYBD) ölçeği toplam puanı arasında istatistiksel olarak anlamlı bir ilișki bulunmamıştır. Alt boyutlarından fiziksel aktivite puan ortalaması, zayıf öğrencilerde düşük iken fazla kilolu öğrencilerde bu oran daha yüksek bulunmuştur $(\mathrm{p}<0.05)$. Tip fakültesi öğrencilerinde yapılan çalışmada BKI ile SYBD ölçeği puanları arasında anlamlı ilişki saptanmamıștır8. Oral'ın çalışmasında öğrencilerin BKI durumları ve SYBD ölçeği puanları değerlendirildiğinde toplam ölçek puanı ile gruplar arasında anlamlı ilişki bulunmamıştır, beslenme alt boyutu obez olanlarda daha düşük, egzersiz alt boyutu fazla 
kilolu olanlarda daha yüksek bulunmuștur ${ }^{10}$. Fazla kilolu katılımcıların fiziksel aktivite alt grup puanlarının diğer katılımclara nazaran daha yüksek olması, bu grupta ki katılımcıların fazla kilolarından dolayı spor aktivitelerine katılımlarının artmasından kaynaklanmış olabileceği kanaatindeyiz.

Öğrencilerin sigara kullanma durumunun ölçek toplam puanına etkisi görülmemiştir ancak sigara kullanan öğrencilerde beslenme alt boyut puanının daha düşük olduğu saptanmıștır $(p<0.05)$. Literatür verilerine bakıldığında benzer çalışmalarda da beslenme puan ortalamalarının sigara içenlerde daha düşük olduğu görülmüştür10,11,29,30. Kara ve İşcan'nın çalışmasında, sigara içen ve içmeyen öğrenciler arasında fark bulunmamıştır ${ }^{23}$. Bu sonuçlar sigara kullanan öğrencilerin sağlık sorumluluğu yeterince yerine getirmedikleri gibi, beslenmelerine de dikkat etmediklerini göstermiştir.

Araştırmamız egzersizin SYBD ölçeği puanı, fiziksel aktivite, beslenme, manevi gelişim, kişilerarası ilişki, stres yönetimi ve sağlık sorumluluğu alt grup puan ortalamalarını pozitif yönde etkilediği saptanmıştır $(\mathrm{p}<0.05)$. Cihangiroğlu ve Deveci'nin araştırmalarında düzenli eğzersiz yapan sağlık meslek yüksekokulu öğrencilerinin SYBD ortalama puanlarının daha yüksek olduğunu bildirilmiștir ${ }^{11}$. Literatür verileri ve elde ettiğimiz veriler ışığında düzenli olarak yapılan egzersizin sağlık üzerindeki pozitif etkisi olduğu düşünülmüştür7,31.

Kronik hastalık durumunun SYBD puan ortalamasına etkisi bir diğer inceleme alanımız idi. Literatürde iki farklı çalışma incelendiğinde hemşireler arasında yapılan araştırmada, kronik hastalığı mevcut katılımcların SYBD ölçek puanının daha yüksek olduğu, üniversite öğrencileri arasında yapılan araştırmada ise sağlık sorumluluğu puanı ve kişiler arası ilişki puanı artarken stres yönetimi puanının azaldığı bildirilmiştir ${ }^{12,23}$. Araştırmamızda kronik hastalık durumu ile ölçek genel ve alt grup puanları arasında ilişkiye rastlanmamıștır. Üniversite öğrencileri arasında yapılan benzer bir çalışmada da verilerimizi destekler düzeyde ölçek puanı ve alt grup puanının kronik hastalık durumu ile ilişkisine rastlanmadığ bildirilmiştir ${ }^{24}$. Elde ettiğimiz veriler ve literatür verileri kronik hastalık durumu ile sağlıklı yaşam davranışları arasında ki ilişkiyi açıklamaya yeterli olamamıştır. Konunun aydınlatılabilmesi için daha geniş ve spesifik çalışmalara ihtiyaç olduğu kanaatindeyiz.

Araştırmaya katılan herhangi bir hobisi olan öğrencilerin SYBD ölçeği puanı, fiziksel aktivite, beslenme, manevi gelişim, kişilerarası ilişki ve stres yönetimi puanı ortalamalarının hobisi olmadığını ifade eden öğrencilerden daha yüksek olduğu saptanmıştır ( $\mathrm{p}<0.01)$. Meslek yüksekokulu öğrencileri üzerinde yapılan benzer bir çalışmada, hobisi olan öğrencilerin SYBD ve tüm alt boyut puanlarının hobisi olmayanlara göre daha yüksek olduğu görülmüştür ${ }^{13}$. Sosyalleşmenin ve boş zamanlarını bir hobi ile değerlendirmenin kişilerin iyilik potansiyelini arttırarak, olumlu yönde sağlık davranışları geliştirdikleri düşünülmüştür.

Araştırma kapsamındaki öğrencilerin aile tipinin SYBD ölçeği puanları arasında anlamlı bir fark bulunmamıştır. Parçalanmış ailede yaşayan öğrencilerin sağlık sorumluluğu puan ortalaması, çekirdek ailede yaşayanlara göre daha düşük saptanmıştır $(\mathrm{p}<0.05)$. Hemşireler arasında yapılan bir çalışmada, SYBD toplam puanı ve alt grupların puan ortalamaları ile aile yapısı arasında ilişkiye rastlanmamıştır ${ }^{21}$. Benzer bir çalışmada, çekirdek aileye sahip hemşirelerin kendini gerçekleştirme alt ölçek puanı daha yüksek bulunmuştur ${ }^{32}$. Lise öğrencileri üzerinde yapılan benzer bir çalışmada, çekirdek ailede yaşayan öğrencilerin SYBD ölçeği toplam puan ortalaması diğer öğrencilere göre daha yüksek olduğu görülmüştür ${ }^{33}$. Aile yapısının kişilerin sağlığı ve 
hastalıkları üzerindeki etkisi düşünüldügünde parçalanmış ailede yetişen bireylerin SYBD ölçeği puanlarının düşük olmasının beklenen bir bulgu olduğu düşünülmüștür.

Sonuç olarak Fırat Üniversitesi Tıp Fakültesi Öğrencilerinin, sağlıklı yaşam biçimi davranışları genel puanı, orta düzeyde bulunmuştur. Sağlığın geliştirilmesine katkıda bulunan davranışlar içerisinde en yüksek ortalamaların sırasıyla kişilerarası ilişki, manevi gelişim ve sağlık sorumluluğu, en düşük ortalamanın ise fiziksel aktiviteye ait olduğu saptanmıştır. Sağlığı geliştirici davranışlar ile ilgili eğitim programları geliştirilmeli ve bu programların sınıf ayrımı yapılmadan tüm eğitim yıllarına yayılacak şekilde ders programının bir parçası haline getirilmelidir. Öğrencilerin fiziksel aktivite yapmaya teşvik edilmesi ve bu konuda gerekli çalışmaların yapılması, spor ve yeşil alanların artırılması ve özellikle kadın öğrencilerin fiziksel aktiviteye daha fazla zaman ayırması ve uygulaması için teşvik edilmelidir.

Etik Kurul Kararı: Araştırma için, Fırat Üniversitesi Girişimsel Olmayan Araştırmalar Etik Kurulu'nun 22.03.2018 tarih ve 06 sayılı yazısı ile etik onay alınmıştır.

Çıkar Çatışması Beyanı: Yazarlar çıkar çatışması olmadığını bildirmişlerdir.

Finansal Destek: Bu çalışma her hangi bir fon tarafından desteklenmemiştir.

Declaration of Conflicting Interests: The authors declare that they have no conflict of interest.

Financial Disclosure: No financial support was received.

\section{KAYNAKLAR}

1. Özvarış ŞB. Halk sağlığı Temel Bilgiler, 1. Baskı, Ankara, Hacettepe Üniversitesi Yayınları, 2006: 1132-6.
2. Allender JA, Spradley WB. Health Promotion and Wellness, Community Health Nursing Conceptand Practice, 5th Edition, USA, Lippincott Williams andWilkins, 2001: 440-45.

3. Bidlack WR. Interrelationships of food, nutrition, diet and health: the national association of state universities and land grant colleges whitepaper. J Am CollNutr. 1996; 15: 422-33.

4. The Bangkok Charter for Health Promotion in a Globalized World. WHO, Geneva. 2005. [cited 2018 May 05]. Available from: http://www.afro.who.int/healthpromotion/ba ngkok_charter_health_promotion.pdf

5. WHO. The World healthreport: 2002 : reducingrisks, promotinghealthy life. [cited 2018 June 06]. Availablefrom: http://www.who.int/whr/2002/en/html

6. İlhan N, Batmaz M, Akhan Utaş L. Üniversite öğrencilerinin sağlıklı yaşam biçimi Davranışları. Maltepe Üniversitesi Hemşirelik Bilim ve Sanatı Dergisi. 2010; 3: 35-44.

7. Ayaz S, Tezcan S, Akıncı F. Hemşirelik yüksekokulu öğrencilerinin sağlığı geliştirme davranışları. C.Ü. Hemşirelik Yüksek Okulu Dergisi. 2005; 9: 26-34.

8. Nacar M, Baykan Z, Cetinkaya F, et al. Health Promoting Lifestyle Behaviour in Medical Students: A Multicentre Study from Turkey. APJCP. 2014; 15: 8969-74.

9. Bozhüyük A, Özcan S. Çukurova Üniversitesi sağlık bilimleri öğrencilerinin sağlıklı yaşam davranışları. Çukurova Üniversitesi Tıp Fakültesi Dergisi. 2016; 41: 664-74.

10. Oral B. Erciyes Üniversitesi Öğrencilerinin Sağlık Algısı ve Sağlıklı Yaşam Biçimi Davranışları. Tıpta Uzmanlık Tezi, Kayseri: Erciyes Üniversitesi Tıp Fakültesi, Halk Sağlığı Anabilim Dalı, 2018.

11. Cihangiroğlu Z, Deveci E. Fırat Üniversitesi Elazı̆̆ Sağlık Yüksekokulu Öğrencilerinin 
Sağlıklı Yașam Biçimi Davranıșları ve Etkileyen Faktörler. Fırat Tıp Dergisi. 2011; 16: 78-83.

12. Örnek ÖK, Kürklü A. Üniversite Öğrencilerinin Sağlıklı Yaşam Biçimi Davranışları, Öz Etkililik-Yeterlilik Düzeyleri ve Etkileyen Faktörler. Türkiye Klinikleri Hemşirelik Bilimleri Dergisi. 2017; 9: 207-17.

13. Vural PI, Bakır N. Meslek Yüksekokulu Öğrencilerinin Sağlıklı Yaşam Biçimi Davranışları ve Etkileyen Faktörler. Acıbadem Üniversitesi Sağlık Bilimleri Dergisi. 2015; 6: 36-42.

14. Wei CN, Harada K, Ueda K, et al. Assessment of health-promoting lifestyle profile in Japanese university students. Environmental Health and Preventive Medicine. 2012; 17: 222-7.

15. UllaDíez SM, Pérez-Fortis A. Sociodemographic predictors of health behaviors in Mexican college students. Health PromotInt. 2009; 25: 85-93.

16. Mašina T, Madžar T, Musil V, Milošević $M$. Differences in Health-PromotingLifestyle Profile Among Croatian Medical Students According to Gender and Year of Study. ActaClinCroat. 2017; 56: 84-91.

17. Walker SN, Hill-Polerecky DM. Psychometric evaluation of the health promoting lifestyle profile II. Unpublished manuscript, University of Nebraska Medical Center, 1996. [cited 2019 May 05]. Available from: http://app1.unmc.edu/Nursing/conweb/HPLP II_Abstract_Dimensions.pdf

18. Bahar Z, Beşer A, Gördes N, Ersin F, Kıssal A. Sağlıklı Yaşam Biçimi Davranışları Ölçeği II'nin Geçerlik ve Güvenirlik Çalışması. C.Ü. Hemşirelik Yüksekokulu Dergisi. 2008; 12: 113.

19. Ozveren H, Cerit B, Ertop NG. Differences in health promoting lifestyle behavior of health management students based upon early diagnosis coverage in a cancer course. Asian Pac J Cancer Prev. 2013; 14: 5769-73.
20. Ozveren H, Yllmaz ED. Investigation of the healthy life style behaviours and the exercise behaviours of the nursing students. International Journal of Human Sciences. 2018; 15: 1505-18.

21. Bostan N, Beşer A. Hemşirelerin Sağlıklı Yaşam Biçimi Davranışlarını Etkileyen Faktörler. Hemşirelikte Eğitim ve Araştırma Dergisi. 2017; 14(1): 38-44.

22. Zafarmand A, Asvar M. Elite DentalStudents: a Cross-SectionalStudy on Different Aspects of Their Life-Style.J Dent (Shiraz). 2017; 18: 251-8.

23. Kara B, İşcan B. Predictors of Health Behaviors in Turkish Female Nursing Students. Asian Nurs Res. 2016; 10: 75-81.

24. Öz Ş. Üniversite Öğrencilerinin Sağlıklı Yaşam Biçimi Davranışları Ve Kardiyovasküler Risk Faktörleri Bilgi Düzeylerinin Belirlenmesi. Yüksek Lisans Tezi, Ankara: Ankara Yıldırım Beyazıt Üniversitesi Sağlık Bilimleri Enstitüsü, Hemşirelik Programı, 2018.

25. Farokhzadian J, Karami A, AzizzadehForouzi M. Health promoting behaviors in nursing students: is it related to self-efficacy for health practices and academic achievement?. Int J AdolescMedHealth. 2018; 20: 1-10.

26. Kazemi DM, Levine MJ, Dmochowski J, Roger Van Horn K, Qi L. Health behaviors of mandated and voluntary students in a motivational intervention program. Prev Med Rep.2015; 2: 423-28.

27. Alkhawaldeh 0 . Health promoting lifestyles of Jordanian University students. International Journal of Advanced Nursing Studies. 2013; 3: 27-31.

28. Yılmazel G, Çetinkaya F, Naçar M. Hemşirelik öğrencilerinde sağlığı geliştirme davranışları. TAF PrevMedBull. 2013; 12: 261-70.

29. Kostak MA, Kurt S, Süt N, Akarsu Ö, Ergül GD. Hemşirelik ve sınıf öğretmenliği öğrencilerinin 
sağlıklı yaşam biçimi davranışları. TAF PrevMedBull. 2014; 13: 189-96.

30. İlhan MN, Özkan S, Aksakal FN, Aslan S, Durukan E, Maral I. Bir Tıp Fakültesi Öğrencilerinde Olası Yeme Bozukluğu Sıklığı. Türkiye'de Psikiyatri.2006; 8: 151-55

31. Özkan S, Yılmaz E. Hastanede çalışan hemşirelerin sağlıklı yaşam biçimi davranışları. Fırat Sağlık Hizmetleri Dergisi. 2008; 3: 90-105.
32. Altay B, Çavuşoğlu F, Güneștaş İ. Tıp Fakültesi Hastanesi'nde Çalışan Hemşirelerin Sağlıklı Yaşam Biçimi Davranışları ve Etkileyen Faktörler. DEUHFED.2015; 8: 12-8.

33. Dağdeviren Z, Şimşek Z. Şanlıurfa il merkezindeki lise öğrencilerinin sağlığı geliştirme davranışları ve ilişkili faktörler. TAF PrevMedBull. 2013; 12: 135-42. 